\title{
Abundance and viability of particle-attached and free-floating bacteria in dusty and nondusty air
}

\author{
Wei Hu${ }^{1,2}$, Kotaro Murata ${ }^{2,3}$, Chunlan Fan ${ }^{2}$, Shu Huang ${ }^{1}$, Hiromi Matsusaki ${ }^{2}$, Pingqing Fu ${ }^{1}$, and Daizhou Zhang ${ }^{2}$ \\ ${ }^{1}$ Institute of Surface-Earth System Science, School of Earth System Science, Tianjin University, Tianjin, 300072, China \\ ${ }^{2}$ Faculty of Environmental and Symbiotic Sciences, Prefectural University of Kumamoto, Kumamoto, 862-8502, Japan \\ ${ }^{3}$ Department of Physics, Tokyo Gakugei University, Tokyo, 184-8501, Japan
}

Correspondence: Daizhou Zhang (dzzhang@pu-kumamoto.ac.jp)

Received: 15 March 2020 - Discussion started: 9 April 2020

Revised: 8 July 2020 - Accepted: 1 August 2020 - Published: 10 September 2020

\begin{abstract}
Airborne bacteria are widespread as a major proportion of bioaerosols, and their coexistence with dust particles enables both bacteria and dust particles to be more active in ice cloud formation and to be harmful to public health. However, the abundance and viability of particleattached and free-floating bacteria in dusty air have not been quantitatively investigated. We researched this subject based on the fact that airborne bacterial cells are approximately $1 \mu \mathrm{m}$ or smaller in aerodynamic diameter; therefore, particleattached bacteria should occur in aerosol samples of particles larger than $1 \mu \mathrm{m}$, and free-floating bacteria should occur among particles smaller than $1 \mu \mathrm{m}$. Our observations at a coastal site in Japan in spring, when the westerlies frequently transported dust from the Asian continent, revealed that particle-attached bacteria in dust episodes, at the concentration of $3.2 \pm 2.1 \times 10^{5}$ cells $\mathrm{m}^{-3}$ on average, occupied $72 \pm 9 \%$ of the total bacteria. In contrast, the fraction was $56 \pm 17 \%$ during nondusty periods, and the concentration was $1.1 \pm 0.7 \times 10^{5}$ cells $\mathrm{m}^{-3}$. The viability, defined as the ratio of viable cells to total cells, of particle-attached bacteria was $69 \pm 19 \%$ in dust episodes and $60 \pm 22 \%$ during nondusty periods on average, both of which were considerably lower than the viabilities of free-floating bacteria (about $87 \%$ ) under either dusty or nondusty conditions. The presented cases suggest that dust particles carried substantial amounts of bacteria on their surfaces, more than half of which were viable, and spread these bacteria through the atmosphere. This implies that dust and bacteria have important roles as internally mixed assemblages in cloud formation and in linking geographically isolated microbial com-
\end{abstract}

munities, as well as possibly having a synergistic impact on human health.

\section{Introduction}

Biological particles in the atmosphere have a potentially significant effect on climate change (Ariya et al., 2009; Delort et al., 2010; Möhler et al., 2007; Zhang et al., 2017); efficiently link microbial communities between continents, islands, and oceans (Fröhlich-Nowoisky et al., 2016; Morris et al., 2011; Caliz et al., 2018); and pose risks to human health (Polymenakou et al., 2008; Reinmuth-Selzle et al., 2017). Representing a high fraction of primary biological particles, airborne bacteria are emitted into the atmosphere from various sources, among which desert dust is a major source (Morris et al., 2011; Pöschl and Shiraiwa, 2015; Pöschl et al., 2010). The co-occurrence of dust and high concentrations of bacteria has been observed frequently in different locations, indicating the widespread nature and dissemination of bacteria with dust at local, regional, and even global scales (Griffin, 2007; Hara and Zhang, 2012; Iwasaka et al., 2009). Limited available observations have revealed the coexistence of mineral and biological contents in ice crystals (Creamean et al., 2013; Pratt et al., 2009), and laboratory experiments have demonstrated that the ice nucleation ability of dust particles is enhanced by biological components, including bacteria in the particles (Boose et al., 2019; Tobo et al., 2019; Conen et al., 2011). Recent toxicological studies with mouse exposure found that the internal mixture of dust and pathogenic bacteria exacerbated pneumonia (He et al., 2012). In addition, the 
attachment of bacteria to dust particles is expected to largely alter the fate of bacterial cells in the air due to protection by the dust particles from harsh environmental conditions (Bowers et al., 2013) and enhanced gravitational settling (Zhang, 2008). All these results reflect that the adherence of bacterial cells to dust particles, i.e., the particle-attached state, and the viability or metabolic capability of bacterial cells are key factors affecting the roles and fate of airborne bacteria in the evolution, development, and conservation of the natural environment.

Quantitative data on the mutual state of airborne bacteria and dust particles in dusty air are without any doubt scientifically very interesting (Schuerger et al., 2018) but are rare because of a lack of available and confident methods, leaving unidentifiable uncertainties in both field observations and model simulations exploring the activities and roles of bacterial cells in atmospheric processes. The cell size distributions for bacteria separated from soils have previously been investigated (Portillo et al., 2013). The survival strategies, dispersal processes, and size distribution of airborne bacteria should be different from those of bacteria in soils. The possible causes are that the aerosolization efficiency of soil bacteria from Earth surfaces varies according to bacterial species and soil types (Joung et al., 2017), and airborne bacteria suffer air turbulence and harsh atmospheric stressors (Hara and Zhang, 2012). Bacteria-associated particles in the air have an aerodynamic diameter significantly larger than the typical size (approximately $1 \mu \mathrm{m}$ ) of individual bacterial cells (Burrows et al., 2009). This is because airborne bacterial cells are favorably attached to coarse particles, such as dust particles and plant debris, or are sometimes found as assemblages of many cells (Després et al., 2012; Iwasaka et al., 2009; Maki et al., 2013; Lighthart, 1997). We quantified the fractions of particle-attached and free-floating bacterial cells in dusty and nondusty air based on the fact that airborne bacterial cells are usually $\sim 1 \mu \mathrm{m}$ or smaller than $1 \mu \mathrm{m}$ (Delort et al., 2010; Després et al., 2012; Pósfai et al., 2003; Burrows et al., 2009; Hara et al., 2011); thus, particle-attached bacteria should be trapped in aerosol samples of particles larger than $1 \mu \mathrm{m}$, and free-floating bacteria should be located among particles smaller than $1 \mu \mathrm{m}$.

By utilizing eight-stage Andersen cascade impactors (Andersen samplers), size-segregated aerosol samples were collected at a southwestern coastal site of Japan in the spring of 2013-2016, when the middle-latitude westerly wind in the Northern Hemisphere frequently brought dust from the Asian continent to the observation site. Viable and nonviable bacteria in each sample were counted using the LIVE/DEAD BacLight bacterial viability assay to estimate bacterial concentrations (Murata and Zhang, 2013, 2016). Bacteria detected in samples of particles larger than $1.1 \mu \mathrm{m}$ (the cutoff size of the sampler stages) were considered particle-attached bacteria, and those in the stages of particles smaller than $1.1 \mu \mathrm{m}$ were considered free-floating bacteria. An analysis of method confidence showed that uncertainties due to the sample collection were small (Figs. S4 and S5 in the Supplement). In this study, we focus on comparisons of the quantitative results of particle-attached and free-floating bacteria in the air and the viability of these bacteria under dusty and nondusty conditions.

\section{Methods}

\subsection{Sample collection and cell enumeration}

Aerosol samples were collected on the platform of a building $\left(32.324^{\circ} \mathrm{N}, 129.993^{\circ} \mathrm{E}, 15 \mathrm{~m}\right.$ above ground level, and $23 \mathrm{~m}$ above sea level) on the seaside of Amakusa, southwestern Japan (Fig. S1), during several observational campaigns in the spring of 2013 to 2016. Dust plumes from the Asian continent, called Asian dust, frequently pass this area in spring. There are limited fishery and agriculture activities and few anthropogenic sources of air pollutants around the area, making the site suitable for investigating airborne bacteria in the Asian continental outflow (Murata and Zhang, 2016).

Aerosol samples were collected onto $0.2 \mu \mathrm{m}$ pore polycarbonate filters $(47 \mathrm{~mm}$; Merck Millipore Ltd., Cork, Ireland) with eight-stage Andersen samplers (Model AN-200; Tokyo Dylec Corp., Japan). The flow rate of the samplers was $28.3 \mathrm{~L} \mathrm{~min}^{-1}$. Aerosol particles were collected onto eight filters according to the particle aerodynamic diameter ranges of $>11,7.0-11,4.7-7.0,3.3-4.7,2.1-3.3,1.1-2.1,0.65-1.1$, and $0.43-0.65 \mu \mathrm{m}$. The collection time of one set of samples was from approximately 3 to $24 \mathrm{~h}$. Details on the sample collection are given in Table 1, Table S1, and Fig. S2 in the Supplement.

Before the collection of each sample set, all stages of the sampler were cleaned carefully, and the plates for the filters were rinsed and wiped with $70 \%$ ethanol in a clean hood to avoid contamination. A blank control for each set of samples was prepared; i.e., a blank filter was set in the sampler without sample collection. After sample collection, the filters were sealed in Petri dishes and stored at $-20^{\circ} \mathrm{C}$ until analysis.

The viable and nonviable bacterial cells (Fig. S3) on the filters were enumerated using the LIVE/DEAD BacLight bacterial viability assay with an epifluorescence microscope (EFM; Eclipse 80i, Nikon Corp., Tokyo, Japan) as described previously (Murata and Zhang, 2016, 2013; Hu et al., 2017). Bacterial cells and other particles were detached from the aerosol-loaded polycarbonate membranes $(47 \mathrm{~mm}$ in diameter) in a phosphate-buffered saline solution (PBS, pH 7.4) by vortex shaking and ultrasonic vibration in ice bath. Then the suspension was treated with glutaraldehyde fixation and stained with the LIVE/DEAD BacLight bacterial viability kit (L13152, Invitrogen ${ }^{\mathrm{TM}}$, Molecular Probes Inc., Eugene, Oregon, US), followed by filtration on a $25 \mathrm{~mm}$ diameter and $0.2 \mu \mathrm{m}$ pore black polycarbonate membrane for bacterial enumeration. An excitation wavelength range between 
Table 1. Concentration and viability of total, free-floating, and particle-attached bacteria. The concentration of coarse particles ( $>1 \mu \mathrm{m})$ and the ratio of particle-attached bacteria to coarse particles are also listed. The percentages of free-floating and particle-attached bacteria are given in the parentheses. The sample ID indicates the sequence number ( 1 to 27 ) of the sample and dust condition (D, dusty; ND, nondusty) and synoptic weather (Pr, prefront; Po, postfront; AA, approaching anticyclone; A, anticyclone) during the sampling period.

\begin{tabular}{|c|c|c|c|c|c|c|c|c|c|}
\hline \multirow{2}{*}{$\begin{array}{l}\text { Sample } \\
\text { ID }\end{array}$} & \multirow{2}{*}{$\begin{array}{l}\text { Synoptic } \\
\text { weather }\end{array}$} & \multirow{2}{*}{$\begin{array}{l}\text { Coarse particles } \\
\qquad\left(10^{5} \mathrm{~m}^{-3}\right)\end{array}$} & \multicolumn{2}{|c|}{ Total bacteria } & \multicolumn{2}{|c|}{ Free-floating bacteria } & \multicolumn{3}{|c|}{ Particle-attached bacteria (PAB) } \\
\hline & & & $\begin{array}{r}\text { Concentration } \\
\left(10^{5} \text { cells } \mathrm{m}^{-3}\right)\end{array}$ & $\begin{array}{r}\text { Viability } \\
(\%)\end{array}$ & $\begin{array}{r}\text { Concentration } \\
\left(10^{5} \text { cells m }^{-3}\right)\end{array}$ & $\begin{array}{r}\text { Viability } \\
(\%)\end{array}$ & $\begin{array}{r}\text { Concentration } \\
\left(10^{5} \text { cells m }^{-3}\right)\end{array}$ & $\begin{array}{r}\text { Viability } \\
(\%)\end{array}$ & $\begin{array}{r}\text { PAB/coarse } \\
\text { particles (\%) }\end{array}$ \\
\hline \multicolumn{10}{|l|}{ Dusty (9) } \\
\hline 1D-Pr & Prefront & 41 & 7.8 & 84 & $1.7(21)$ & 90 & $6.1(79)$ & 82 & 15 \\
\hline 2D-Po & Postfront & 32 & 2.3 & 77 & $0.5(23)$ & 99 & $1.8(77)$ & 71 & 6 \\
\hline 3D-AA & $\begin{array}{l}\text { Approaching } \\
\text { anticyclone }\end{array}$ & 12 & 2.2 & 89 & $0.7(30)$ & 91 & $1.6(70)$ & 88 & 13 \\
\hline 4D-Pr+Po & Pre-/postfront & 52 & 7.3 & 61 & $1.8(25)$ & 71 & $5.4(75)$ & 58 & 11 \\
\hline 5D-AA & $\begin{array}{l}\text { Approaching } \\
\text { anticyclone }\end{array}$ & 21 & 4.7 & 63 & $0.7(16)$ & 79 & $3.9(84)$ & 60 & 19 \\
\hline 10D-Po & Postfront & 16 & 2.5 & 40 & $0.6(25)$ & 61 & $1.9(75)$ & 33 & 11 \\
\hline $17 \mathrm{D}-\mathrm{AA}$ & $\begin{array}{l}\text { Approaching } \\
\text { anticyclone }\end{array}$ & 88 & 2.9 & 73 & $1.0(36)$ & 99 & $1.9(64)$ & 59 & 2 \\
\hline 26D-Po & Postfront & 10 & 8.2 & 95 & $2.5(30)$ & 97 & $5.7(70)$ & 95 & 59 \\
\hline 27D-AA & $\begin{array}{l}\text { Approaching } \\
\text { anticyclone }\end{array}$ & 15 & 1.9 & 87 & $0.9(46)$ & 96 & $1.0(54)$ & 78 & 7 \\
\hline Average & & $32 \pm 25$ & $4.4 \pm 2.6$ & $74 \pm 17$ & $1.2 \pm 0.7(28 \pm 9)$ & $87 \pm 14$ & $3.2 \pm 2.1(72 \pm 9)$ & $69 \pm 19$ & $16 \pm 17$ \\
\hline \multicolumn{10}{|l|}{ Nondusty (18) } \\
\hline 6ND-AA & $\begin{array}{l}\text { Approaching } \\
\text { anticyclone }\end{array}$ & 13 & 1.5 & 75 & $0.4(27)$ & 88 & $1.1(73)$ & 70 & 9 \\
\hline 7ND-A & Anticyclone & 12 & 1.5 & 74 & $0.6(39)$ & 82 & $0.9(61)$ & 69 & 8 \\
\hline $8 \mathrm{ND}-\mathrm{A}+\mathrm{Pr}$ & Anticyclone+ & 14 & 0.8 & 98 & $0.2(31)$ & 99 & $0.5(69)$ & 98 & 4 \\
\hline 9ND-Pr & $\begin{array}{l}\text { prefront } \\
\text { Prefront }\end{array}$ & 26 & 2.7 & 73 & $1.9(71)$ & 84 & $0.8(29)$ & 45 & 3 \\
\hline $11 \mathrm{ND}-\mathrm{AA}$ & $\begin{array}{l}\text { Approaching } \\
\text { anticyclone }\end{array}$ & 4 & 2.1 & 72 & $1.3(64)$ & 85 & $0.8(36)$ & 51 & 18 \\
\hline 12ND-A & Anticyclone & 14 & 2.9 & 83 & $2.1(73)$ & 96 & $0.8(27)$ & 48 & 6 \\
\hline 13ND-A & Anticyclone & 9 & 3.6 & 75 & $2.5(70)$ & 86 & $1.1(30)$ & 50 & 12 \\
\hline 14ND-A & Anticyclone & 13 & 1.9 & 77 & $0.8(42)$ & 99 & $1.1(58)$ & 62 & 9 \\
\hline $15 \mathrm{ND}-\mathrm{AA}$ & $\begin{array}{l}\text { Approaching } \\
\text { anticyclone }\end{array}$ & 10 & 4.4 & 65 & $1.0(24)$ & 61 & $3.4(76)$ & 66 & 35 \\
\hline 16ND-Po & Postfront & 16 & 2.5 & 89 & $0.9(35)$ & 96 & $1.6(65)$ & 85 & 10 \\
\hline 18ND-AA & $\begin{array}{l}\text { Approaching } \\
\text { anticyclone }\end{array}$ & 15 & 2.9 & 91 & $0.5(18)$ & 86 & $2.4(82)$ & 92 & 16 \\
\hline 19ND-A & Anticyclone & 9 & 1.1 & 72 & $0.4(35)$ & 96 & $0.7(65)$ & 59 & 7 \\
\hline 20ND-A & Anticyclone & 10 & 1.0 & 77 & $0.4(41)$ & 85 & $0.6(59)$ & 72 & 6 \\
\hline 21ND-A & Anticyclone & 13 & 1.7 & 63 & $1.0(63)$ & 89 & $0.6(37)$ & 18 & 5 \\
\hline 22ND-A & Anticyclone & 8 & 1.2 & 40 & $0.5(43)$ & 56 & $0.7(57)$ & 28 & 9 \\
\hline 23ND-Pr+Po & Pre-/postfront & 12 & 1.1 & 59 & $0.5(48)$ & 88 & $0.6(52)$ & 32 & 5 \\
\hline 24ND-Po+A & $\begin{array}{l}\text { Postfront/ } \\
\text { Anticyclone }\end{array}$ & 7 & 1.4 & 72 & $0.5(38)$ & 88 & $0.8(62)$ & 62 & 12 \\
\hline $25 \mathrm{ND}-\mathrm{A}$ & Anticyclone & 6 & 1.5 & 85 & $0.6(40)$ & 95 & $0.9(60)$ & 78 & 15 \\
\hline Average & & $12 \pm 5$ & $2.0 \pm 1.0$ & $75 \pm 13$ & $0.9 \pm 0.7(44 \pm 17)$ & $87 \pm 12$ & $1.1 \pm 0.7(56 \pm 17)$ & $60 \pm 22$ & $10 \pm 7$ \\
\hline \multicolumn{10}{|l|}{ All (27) } \\
\hline Average & & $18 \pm 18$ & $2.8 \pm 2.0$ & $74 \pm 14$ & $1.0 \pm 0.7(39 \pm 16)$ & $87 \pm 12$ & $1.8 \pm 1.7(61 \pm 16)$ & $63 \pm 21$ & $12 \pm 11$ \\
\hline
\end{tabular}


450 and $490 \mathrm{~nm}$ (blue) was utilized, and the microscope was operated at $1000 \times$ magnification. Fluorescent green and red/orange/yellow cells with spherical shape and size close to or smaller than $1 \mu \mathrm{m}$ in diameter were counted as viable and nonviable bacteria, respectively. There are uncertainties in the bacterial cell counting caused by the LIVE/DEAD BacLight bacterial viability kit because the kit could not distinguish archaea and small eukaryotes including fungi from bacteria (Berney et al., 2007). Since the abundance of archaea and fungi in air could be several (1-6) orders of magnitude less than that of bacteria (Fröhlich-Nowoisky et al., 2014, 2016; Delort et al., 2010) and the dominant size range of fungal spores is $2-10 \mu \mathrm{m}$ (Bauer et al., 2008), the overestimation of bacteria caused by the kit we used should be less than $10 \%$, although the uncertainties could not be quantitatively evaluated. The cell concentrations in the sizesegregated particles in the air were estimated based on cell counts and the sampling of air volumes following the subtraction of the blank controls. The viability of a group of bacterial cells was defined as the ratio of the viable bacterial cells to total bacterial cells. The procedure for the experimental operation and the formulations for the estimation of cell concentrations are given in the Supplement (Sect. S1 in the Supplement).

The collection efficiency of airborne bacterial cells with Andersen samplers was evaluated by comparing the results to those obtained by using BioSamplers (SKC Inc., Eighty Four, PA, US) and in-line filter holders (47 mm, Millipore Corp., Billerica, MA, US). The comparison shows that the total bacterial concentration results of the Andersen sampler were generally consistent with those of the BioSamplers and the in-line filter holders (Fig. S4).

\subsection{Separation of particle-attached and free-floating bacteria}

In this study, bacteria in the samples of stages with particles larger than $1.1 \mu \mathrm{m}$ were considered particle-attached, and bacteria in the samples of stages with particles ranging from 0.43 to $1.1 \mu \mathrm{m}$ were considered free-floating. The resuspension of bacteria trapped by upper stages and falling onto lower stages during sample collection may cause uncertainties in the size distribution of bacteria-associated particles and the separation of particle-attached and free-floating bacteria.

The uncertainties in the estimation of particle-attached and free-floating bacteria were investigated in the laboratory (Sect. S2 in the Supplement). The fractions and concentrations of particle-attached bacteria obtained by the presented method were potentially underestimated. But the underestimation did not significantly affect the size distributions of particle-attached bacteria, and, in particular, the underestimation of the concentrations of particle-attached bacterial cells was less than $10 \%$ on average (Fig. S5). The total bacterial concentration results of the Andersen sampler were gener- ally consistent with those of the in-line filter holders collecting total particles (Fig. S4). This result indicates that bacteria smaller than $0.43 \mu \mathrm{m}$, which are not available by the Andersen samplers in this study, were a minor fraction of the freefloating bacteria.

\subsection{Atmospheric conditions}

During the observation periods, the number concentrations of size-segregated airborne particles $(>0.3,>0.5,>1.0,>2.0$, and $>5.0 \mu \mathrm{m}$ in diameter) were monitored with optical particle counters (OPC, KC-01D in 2013 and KC-01E in 20142016, Rion Co., Ltd., Tokyo, Japan). In this study, fine particles are in the range of $0.3-1.0 \mu \mathrm{m}$, and those larger than $1.0 \mu \mathrm{m}$ are referred to as coarse particles. Meteorological conditions, including temperature, pressure, relative humidity, precipitation, and wind speed and direction, were monitored with a weather transmitter (WXT520, Vaisala Inc., Helsinki, Finland). Airborne particle number concentrations and meteorological data during the observation periods are summarized in Fig. S2 and Table 1.

On the basis of surface pressure and weather charts in the days before and after sample collection (Figs. S2 and S6), the air parcels on the synoptic scales from which samples were collected were categorized into four groups: prefront, postfront, approaching anticyclone, and anticyclone (Tables 1 and S1). Details of the categorization are available in Murata and Zhang (2016).

Dust episodes were identified by significant increases in coarse particle concentrations $(>1 \mu \mathrm{m})$, the forecast for Asian dust distributions in the east Asian region (http: //www-cfors.nies.go.jp/ cfors/, last access: 8 September 2020; Fig. S7), and the backward trajectory of air masses calculated with the NOAA hybrid single-particle Lagrangian integrated trajectory (HYSPLIT) model (http://ready.arl.noaa. gov/HYSPLIT_traj.php, last access: 8 September 2020). During dust events, the coarse particle concentration largely increased at the study site (Zhang et al., 2003). Dust particles were present in the postfront air and sometimes in the approaching anticyclone air. The results of backward trajectory analysis during dusty and nondusty episodes are shown in Fig. S8.

\section{Results}

\subsection{Concentrations of airborne bacteria in segregated size ranges}

The concentrations of bacterial cells, including viable and nonviable cells, generally showed a bimodal number size distribution during dust episodes (e.g., Fig. 1a, b, d, f). Most of the bacteria were present in particle fractions with aerodynamic size $\left(D_{\mathrm{p}}\right)$ ranges larger than $2 \mu \mathrm{m}$ (i.e., $2.1-3.3,3.3-$ 4.7 and $4.7-7.0 \mu \mathrm{m}$; Fig. S9). These sizes are larger than the size of individual airborne bacterial cells (approximately 


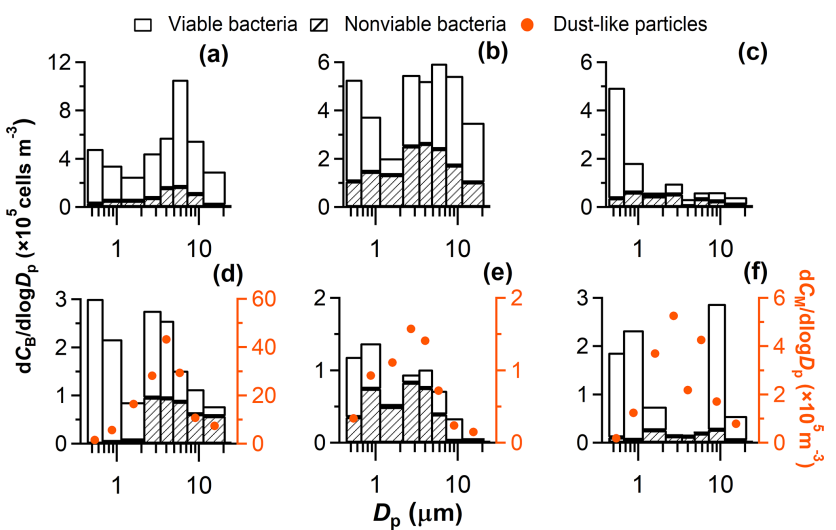

Figure 1. Concentrations of viable and nonviable bacteria $\left(C_{\mathrm{B}}\right)$ and mineral dust-like particles $\left(C_{\mathrm{M}}\right)$ in size-segregated airborne particles. Selected samples are shown as examples: (a) 1D-Pr, (b) 4DPr+Po, (c) 11ND-AA, (d) 17D-AA, (e) 22ND-A, (f) 27D-AA. The results of all sampling periods are depicted in Fig. S9 in the Supplement.

$1 \mu \mathrm{m}$ or smaller), indicating that the bacteria did not float individually in the air but were combined with other particles or were agglomerates of bacterial cells; i.e., the bacteria were particle-attached. The agglomerates of bacterial cells usually appear near emission sources, e.g., sea spray and leaf water (Lighthart, 1997) and probably contributed a limited portion to particle-attached bacteria in this study. There were also many bacterial cells in the size ranges smaller than $1.1 \mu \mathrm{m}$, i.e., free-floating bacterial cells. Their concentration was comparable to or lower than the concentrations of bacteria in the larger size ranges (Figs. 1 and S9).

In contrast to dust episodes, during nondusty periods, the number size distribution of bacteria largely varied and did not show any trend with respect to weather conditions. In six cases during nondusty periods (9ND-Pr, 11ND-AA, 12NDA, 13ND-A, 14ND-A, and 21ND-A; Fig. S9), the bacteria appeared mainly in size ranges smaller than $1.1 \mu \mathrm{m}$ and accumulated the most in the size range of $0.43-0.65 \mu \mathrm{m}$ (e.g., Fig. 1c), indicating the predominance of free-floating bacteria. During most of the other nondusty periods (6ND-AA, 7ND-A, 8ND-A+Pr, 16ND-Po, 19ND-A, 20ND-A, 22NDA, 23ND-Pr+Po, 24ND-Po+A, and 25ND-A), the distributions of bacteria were similar to those during the dust periods, although the concentrations were much lower than or comparable to those in the dust episodes (e.g., Fig. 1e). There were two exceptional cases in nondusty periods that had a monomodal distribution, with peaks at 3.3-4.7 $\mu \mathrm{m}$ (15ND-AA) or larger than $11 \mu \mathrm{m}$ (18ND-AA) (Fig. S9). Multiple processes including advection, deposition, local emission, and local convective mixing could influence the size distributions. Unfortunately, we do not have enough case data to investigate statistically meaningful connections between the size distribution and those processes.

\subsection{Concentration of particle-attached and free-floating bacteria}

The report of results when data are non-normal distribution should be viewed with caution, since many statistical analyses (e.g., the average and standard deviation) are only applicable to random samples from populations with a normal distribution. Aerobiological data possibly do not have a normal distribution (Kasprzyk and Walanus, 2014; Limpert et al., 2008). Conversely, in this study, to make the comparisons among the values easily understood and avoid misunderstanding, we assume the data are normally distributed.

On average, the concentration of total bacterial cells, $4.4 \pm 2.6 \times 10^{5}$ cells m$^{-3}$, during dust episodes was more than twice that during nondusty periods, $2.0 \pm 1.0 \times 10^{5}$ cells m $^{-3}$ (Table 1). This large difference (independent sample $t$ test, $p<0.05)$ in concentration is consistent with the results of previous studies (Hara and Zhang, 2012; Yamaguchi et al., 2014). The concentrations of particle-attached bacterial cells during dust episodes and nondusty periods were $3.2 \pm 2.1 \times 10^{5}$ and $1.1 \pm 0.7 \times 10^{5}$ cells m$^{-3}$, respectively. During dust periods particle-attached bacteria accounted for $72 \pm 9 \%$ of total bacterial counts, while during nondusty periods particle-attached bacteria occupied a much lower proportion of $56 \pm 17 \%$ (independent sample $t$ test, $p<0.05$ ). These results suggest that dust particles carry a substantial amount of bacterial cells on their surfaces from dust source areas to remote downstream areas.

On the other hand, the percentage of free-floating bacterial cells was in some cases higher than $70 \%$ during nondusty periods (Table 1). In particular, the percentage ranged from $35 \%$ to $73 \%$ ( $49 \pm 15 \%$ on average) under anticyclone weather conditions, when the air mass moved sluggishly and was mainly influenced by marine and local emissions and less by continental emissions (Fig. S8). Therefore, a substantial fraction of airborne bacteria were free-floating, and they were frequently the common bacteria in nondusty air.

The number ratio of particle-attached bacteria to particles in the size range larger than $1.1 \mu \mathrm{m}$ was $12 \pm 11 \%$ on average (Table 1). Except for two periods when the ratios were $35 \%$ and $59 \%$, the ratio was approximately stable $(9 \pm 5 \%$ on average for the other periods), regardless of dust episodes and nondusty periods (Table 1). That is, assuming that a bacteria-attached coarse particle harbors at least one bacterial cell, coarse particles including mineral dust particles with attached bacteria usually made up less than $9 \%$ of the total coarse particles. Maki et al. (2008) reported that the mineral particles with attached bacteria made up approximately $10 \%$ of the total mineral particles, with the remaining mineral particles possessing few or no bacterial cells at $800 \mathrm{~m}$ height above the ground in an Asian dust source region, Dunhuang, China.

The number size distributions of bacterial cells and mineral-dust-like particles (insoluble and with irregular shapes; Fig. S3) in the microscope fields of some samples 
were compared. In most cases, the size distributions (mode sizes) of mineral-dust-like particles and bacteria in the size ranges larger than $1.1 \mu \mathrm{m}$ showed very good consistency (Figs. 1 and S9). In some cases, the concentration of bacteria in the size ranges larger than $1.1 \mu \mathrm{m}$, especially nonviable bacteria, was closely correlated with the mineral dustlike particles in the size-segregated samples (Fig. 2). These results further confirm that the bacteria observed in the large size ranges were closely associated with airborne coarse particles; i.e., they were particle attached. In some cases, the mode size ranges of the bacterial cells and the dust-like particles were inconsistent (Fig. S9), likely because the number of bacteria on the surface of each coarse particle largely varied or there were less dust-like particles in the coarse size ranges (e.g., 26D-Po). Dust-like particles were rarely observed in the size ranges smaller than $1.1 \mu \mathrm{m}$ (Fig. S9), further indicating that the bacteria observed in those size ranges were predominantly free-floating.

\subsection{Viabilities of particle-attached and free-floating bacteria}

The viability of particle-attached bacteria varied over a wide range from $18 \%$ to $98 \%(63 \pm 21 \%$ on average), and the viability of free-floating bacteria was between $56 \%$ and $99 \%$ ( $87 \pm 12 \%$ on average) (Table 1$)$, much higher than the viability of particle-attached bacteria (paired-sample $t$ test, $p=0.00$ ). The attachment of airborne bacteria to larger particles is expected to be favorable for retaining the viability or cultivability of cells and may indirectly increase the diversity of bacterial communities because of the possible protection of bacterial cells from harsh atmospheric conditions (Bowers et al., 2013; Prospero et al., 2005; Lighthart, 2000).

However, we found that the viability of particle-attached bacteria tended to be lower than that of free-floating bacteria, regardless of weather conditions (Table 1). This result indicates that a fraction of the particle-attached bacterial cells were either nonviable when they were blown into the air with the dust or had experienced atmospheric stressors for several days during long-distance transport and changed from a viable to a nonviable state. This is also likely the reason for the poor correlation (Pearson correlation $r=0.35, p=0.075$ ) between the viability of particle-attached bacteria and the ratio of particle-attached bacteria to coarse particles (Table 1). In contrast, a large fraction of free-floating bacteria were viable. A fraction of these bacteria were likely from local areas, with a residence time (usually less than $1 \mathrm{~d}$ ) shorter than that (2-3 d) of the particle-attached bacteria transported from the Asian continent (Fig. S8). The proportion of free-floating bacteria was higher under nondusty conditions when the air masses moved slowly above the marine area. However, for special cases, such as the one of 20ND-A when the air was from the north due to the specific weather of west high pressure versus east low pressure in the westerly, a substantial fraction of the bacteria could be from the local and close ar-

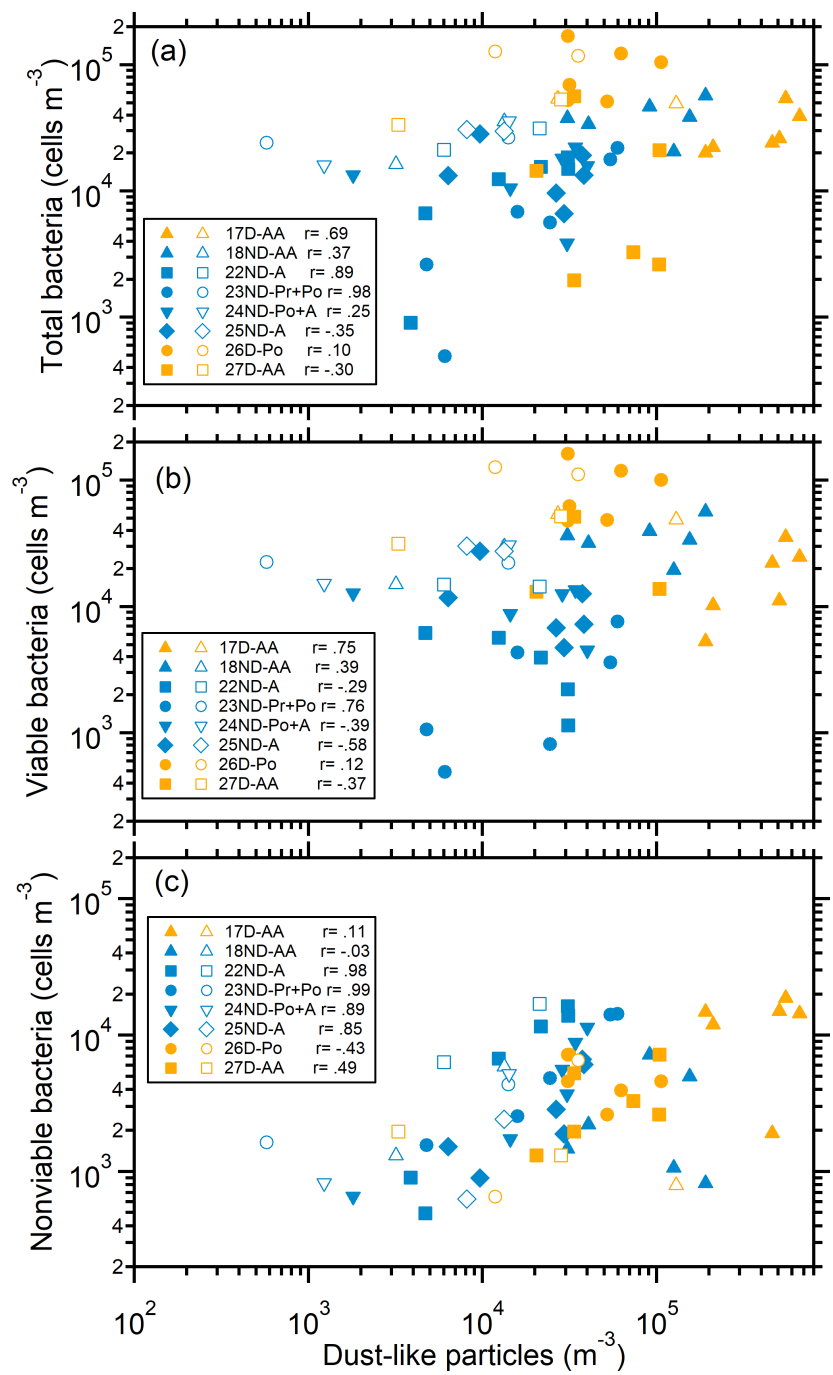

Figure 2. Relationship between bacteria and mineral-dust-like particles in size-segregated aerosols. (a) Total bacteria, (b) viable bacteria, and (c) nonviable bacteria. Solid and open markers represent particles in the size ranges larger and smaller than $1.1 \mu \mathrm{m}$, respectively. The Pearson correlation coefficients $(r)$ between bacteria and mineral-dust-like particles for particles larger than $1.1 \mu \mathrm{m}$ are shown.

eas due to the extremely strong wind. In terms of concentration, viable particle-attached bacteria were usually more abundant than viable free-floating bacteria in dust episodes (Figs. 1 and S9).

On average, the viability $(74 \pm 17 \%)$ of total bacteria in dusty episodes was close to the viability $(75 \pm 13 \%)$ of total bacteria during nondusty periods (Table 1). The viability of particle-attached bacteria $(69 \pm 19 \%)$ during dust periods was slightly higher than that $(60 \pm 22 \%)$ during nondusty periods. The majority of particle-attached bacteria were viable.

Free-floating bacteria exhibited a quite high viability, and the viabilities of the bacteria in dusty $(87 \pm 14 \%$ on average) and nondusty $(87 \pm 12 \%)$ air were similar. The con- 
centration of viable free-floating bacteria was $3.8 \times 10^{4}$ $1.5 \times 10^{5}$ cells m$^{-3}$, which was lower than that of particleattached bacteria $\left(6.2 \times 10^{4}-5.1 \times 10^{5}\right.$ cells m$\left.^{-3}\right)$. An increase in viable free-floating bacteria on the order of $10^{5}$ cells $\mathrm{m}^{-3}$ $\left(1.1-2.2 \times 10^{5}\right.$ cells $\left.^{-3}\right)$ was observed when the weather was fine and the air masses moved slowly from marine areas (e.g., 9ND-Pr, 12ND-A, and 13ND-A), favoring the accumulation of bacteria emitted from local areas (Fig. S8).

\section{Discussion}

\subsection{Implication from the comparison with literature data}

There are few data on airborne bacterial cells available for comparison with the present study. Observations in the multiphase atmosphere with culture-dependent methods revealed that approximately $60 \%-90 \%$ or even more culturable airborne bacteria were present in the size range of particles larger than $1.1 \mu \mathrm{m}$ (Agarwal, 2017; Burrows et al., 2009; Montero et al., 2016; Raisi et al., 2013), and the median aerodynamic diameter of particles containing culturable bacteria was approximately $2-4 \mu \mathrm{m}$ at diverse sites (Lighthart, 2000; Raisi et al., 2013; Shaffer and Lighthart, 1997; Tong and Lighthart, 2000). These results indicate the predominance of culturable particle-attached bacteria in the air, which is approximately in line with the results under dusty and nondusty conditions of this study.

Early studies with single-particle analysis frequently encountered the mode size of biological aerosol particles in the size range smaller than $1 \mu \mathrm{m}$ (Matthias-Maser et al., 1999; Matthias-Maser and Jaenicke, 1995, 2000). In contrast, recent real-time measurements using ultraviolet aerodynamic particle sizer spectrometers and wideband integrated bioaerosol sensor techniques revealed the mode size of fluorescent biological aerosol particles (FBAPs) to be approximately $2-6 \mu \mathrm{m}$, and the particles were mainly attributed to fungal spores (Pöschl et al., 2010; Savage et al., 2017; Yue et al., 2017; Huffman et al., 2010). However, the abundant particle-attached bacteria identified in this study in size ranges larger than $2 \mu \mathrm{m}$ indicate dust-particle-attached bacteria should not compose small fractions of real-time FBAP results in the relevant size ranges. In addition, the mode at or smaller than $1 \mu \mathrm{m}$ observed in real-time FBAP studies is likely consistent with the presence of free-floating bacterial cells in the present study, but the comparison and discussion on the data are not confident because of the large uncertainties caused by the low counting efficiency and accuracy in submicron size ranges of the instruments used in the studies (Yue et al., 2017; Huffman et al., 2010).

Since other equivalent data for comparison are rare, we discuss the influences of airborne bacteria according to the results obtained in this study and relevant general understandings in the following subsections.

\subsection{Ice cloud formation}

Dust particles from desert areas are constantly spread at local, regional, and global scales in the atmosphere. These particles transport microorganisms across continents and oceans to remote downstream areas (Griffin, 2007; Schuerger et al., 2018). It has been shown that bacteria in the air are more effective ice nuclei at temperatures up to $-2{ }^{\circ} \mathrm{C}$ than abiotic particles (Ariya et al., 2009; Burrows et al., 2013; FröhlichNowoisky et al., 2016; Möhler et al., 2007). Biological particles coexisting with dust particles have been detected in ice residues sampled from clouds (Creamean et al., 2013; Pratt et al., 2009), and the coexistence of dust and bacterial cells increases the ability of particles to act as ice nuclei for ice crystal formation (Tobo et al., 2019). Proteins in bacteria are ice nucleation active sites and are well protected when bacteria adhere to mineral dust surfaces (Conen et al., 2011). The attachment of bacteria to dust particles possibly increases the number of sites for ice nucleation and consequently the ice nucleation ability of dust particles (Boose et al., 2019; Conen et al., 2011; Augustin-Bauditz et al., 2016). The present results show that up to $1 / 10$ or more dust particles could be bacteria carriers, and the concentration of particle-attached bacteria, i.e., the number of bacteria-dust contact sites in dust episodes, was on average 3 times larger than that during nondusty periods (Table 1). The occurrence of dust in remote downstream areas will significantly increase not only the concentration of bacterial cells but also the concentration of dust-bacteria mixture particles and the number of ice nucleation active sites. This phenomenon could provide important sources of nuclei for ice cloud formation under saturated meteorological conditions for icing, particularly in remote elevated air, where the concentrations of aerosol particles able to act as nuclei are usually very low (Creamean et al., 2013).

\subsection{Ecosystem conservation and development}

More than $60 \%$ of particle-attached bacteria and approximately $87 \%$ of free-floating bacteria in the dusty air remained viable. Airborne bacteria can multiply more easily after they settle into water (lakes, rivers, and oceans) and soil surfaces than in the atmosphere. As a consequence, their dissemination via the atmosphere has the potential to alter the microbial biogeography, biogeochemistry, and ecosystem services of downstream areas. Moreover, a recent study on phosphorus in aerosol particles in Asian continental outflow revealed that natural dust particles supplied higher ratios of bioavailable phosphorus than other types of particles as nutrients for the primary production in marine ecosystems, and the phosphorus was presumed to be from the biological particles in dust plumes (Shi et al., 2019). The dissemination of bacteria with dust in the air is much more efficient than that via other routes, such as rivers, because dust in the atmosphere can travel globally within 2 weeks (Uno et al., 2009). Therefore, the wide dispersal of atmospheric dust is an effi- 
cient link between bacterial communities in geographically isolated ecosystems. This linking function is likely the key process that constantly blurs the distinctions between closely related microbial species in distant areas. Thus, the diversities of microorganisms have a geographically weak gradient at the global scale and are functions of habitat properties but not of historical/evolutionary factors (Fenchel and Finlay, 2004).

\subsection{Health effects}

Allergenic and toxic bacteria inhaled and deposited on the surface of upper respiratory tracts and lungs are suggested to provoke severe adverse health effects, regardless of whether the bacteria are viable, dead, or cell fragments (Fröhlich-Nowoisky et al., 2016; Després et al., 2007). Dust particles carrying biological materials, including bacteria with pathogenic, allergenic, and adjuvant activity, can cause and aggravate respiratory disorders (Reinmuth-Selzle et al., 2017). The size distribution of bacteria-related particles in the air is particularly meaningful because the movement and deposition of the particles in the airways are size-dependent. Particles larger than $0.5 \mu \mathrm{m}$ are deposited by sedimentation and impaction mainly in the head airways, and particles smaller than $0.5 \mu \mathrm{m}$ can reach the lower airways by diffusion (Fröhlich-Nowoisky et al., 2016). According to the size distribution of the airborne bacteria-related particles in this study (Figs. 1 and S9), the deposition fraction and abundance of particle-attached bacteria are much higher than those of individual cells in both the upper and the lower airways. Polymenakou et al. (2008) reported that a large fraction of airborne bacteria at respiratory particle sizes $(<3.3 \mu \mathrm{m})$ during an intense dust event were phylogenetic neighbors to human pathogens. He et al. (2012) suggested that Asian dust caused the exacerbation of pneumonia induced by Klebsiella pneumoniae due to the enhanced production of pro-inflammatory mediators in alveolar macrophages. Therefore, free-floating bacterial cells are likely to more easily influence the deep parts than the upper parts of respiratory airways, while the negative influence of particle-attached bacteria, particularly under dust conditions, is expected to be more serious in the upper parts than in the deep parts of respiratory airways.

\section{Conclusions}

In this study, we aimed to quantify the particle-attached and free-floating bacteria in dusty and nondusty air in southwestern Japan using the fluorescent enumeration of bacterial cells in size-segregated aerosol samples. The bacteria showed bimodal number size distributions during dust episodes, while the distributions largely varied during nondusty periods. Particle-attached bacteria in dust episodes, with a concentration of $3.2 \pm 2.1 \times 10^{5}$ cells m$^{-3}$ on average, occupied $72 \pm 9 \%$ of the total bacteria. In contrast, this percentage was $56 \pm 17 \%$ during nondusty periods, with a concentration of $1.1 \pm 0.7 \times 10^{5}$ cells $\mathrm{m}^{-3}$. The results indicate that dust particles conveyed substantial numbers of bacterial cells on their surfaces. Viable particle-attached bacteria were more abundant than viable free-floating bacteria in dusty air, which is compatible with the previous results that larger particles harbor more viable and/or culturable bacteria than smaller particles.

The viability (approximately $63 \pm 21 \%$ ) of particleattached bacteria was much lower than that $(87 \pm 12 \%)$ of free-floating bacteria, likely because atmospheric stressors along with long-distance transport inhibited the survival of particle-attached bacteria and the entrainment of locally originating free-floating bacteria. High concentrations and viabilities of free-floating bacteria were observed in stagnant air, mostly under anticyclone conditions, suggesting that locally emitted bacteria accounted for the major fractions.

The present results, quantitatively showing the state of airborne bacteria in association with particles, i.e., particleattached and free-floating bacteria, could have broad implications in the disciplines of atmospheric sciences, ecology, public health, and climate. In addition, the methods used in this study are low cost and easily available but are time- and labor-intensive. Verification of the status of airborne bacteria using efficient techniques, such as in situ electron microscopy, and the exploration of the compositions, functions, and activities of particle-attached and free-floating bacteria in the atmosphere are necessary to deepen our understanding of the related fields.

Data availability. All data are available from the corresponding author upon request. Datasets for Figs. 1 and 2 are given in Tables S2 and S3 in the Supplement.

Supplement. The supplement related to this article is available online at: https://doi.org/10.5194/bg-17-4477-2020-supplement.

Author contributions. DZ and WH designed the research. WH, $\mathrm{KM}, \mathrm{CF}$, and $\mathrm{SH}$ performed the research. WH, KM, and DZ analyzed data and wrote the paper. HM and PF reviewed and commented on the paper.

Competing interests. The authors declare that they have no conflict of interest.

Acknowledgements. We thank Yuka Horikawa, Megumi Mukogawa, and Miki Miyamoto for their assistance with sampling and analysis. 
Financial support. This research has been supported by the Japan Society for the Promotion of Science KAKENHI (grant nos. JP16H02492 and 17K18811) and the National Natural Science Foundation of China (grant nos. 41805118 and 41977183).

Review statement. This paper was edited by Carolin Löscher and reviewed by three anonymous referees.

\section{References}

Agarwal, S.: Seasonal variability in size-segregated airborne bacterial particles and their characterization at different source-sites, Environ. Sci. Pollut. Res., 24, 13519-13527, https://doi.org/10.1007/s11356-017-8705-2, 2017.

Ariya, P. A., Sun, J., Eltouny, N. A., Hudson, E. D., Hayes, C. T., and Kos, G.: Physical and chemical characterization of bioaerosols - Implications for nucleation processes, Int. Rev. Phys. Chem., 28, 1-32, https://doi.org/10.1080/01442350802597438, 2009.

Augustin-Bauditz, S., Wex, H., Denjean, C., Hartmann, S., Schneider, J., Schmidt, S., Ebert, M., and Stratmann, F.: Laboratorygenerated mixtures of mineral dust particles with biological substances: characterization of the particle mixing state and immersion freezing behavior, Atmos. Chem. Phys., 16, 5531-5543, https://doi.org/10.5194/acp-16-5531-2016, 2016.

Bauer, H., Claeys, M., Vermeylen, R., Schueller, E., Weinke, G., Berger, A., and Puxbaum, H.: Arabitol and mannitol as tracers for the quantification of airborne fungal spores, Atmos. Environ., 42, 588-593, https://doi.org/10.1016/j.atmosenv.2007.10.013, 2008.

Berney, M., Hammes, F., Bosshard, F., Weilenmann, H. U., and Egli, T.: Assessment and interpretation of bacterial viability by using the LIVE/DEAD BacLight Kit in combination with flow cytometry, Appl. Environ. Microbiol., 73, 3283-3290, https://doi.org/10.1128/AEM.02750-06, 2007.

Boose, Y., Baloh, P., Plötze, M., Ofner, J., Grothe, H., Sierau, B., Lohmann, U., and Kanji, Z. A.: Heterogeneous ice nucleation on dust particles sourced from nine deserts worldwide Part 2: Deposition nucleation and condensation freezing, Atmos. Chem. Phys., 19, 1059-1076, https://doi.org/10.5194/acp19-1059-2019, 2019.

Bowers, R. M., Clements, N., Emerson, J. B., Wiedinmyer, C., Hannigan, M. P., and Fierer, N.: Seasonal variability in bacterial and fungal diversity of the near-surface atmosphere, Environ. Sci. Technol., 47, 12097-12106, https://doi.org/10.1021/es402970s, 2013

Burrows, S. M., Elbert, W., Lawrence, M. G., and Pöschl, U.: Bacteria in the global atmosphere - Part 1: Review and synthesis of literature data for different ecosystems, Atmos. Chem. Phys., 9, 9263-9280, https://doi.org/10.5194/acp-9-9263-2009, 2009.

Burrows, S. M., Hoose, C., Pöschl, U., and Lawrence, M. G.: Ice nuclei in marine air: biogenic particles or dust?, Atmos. Chem. Phys., 13, 245-267, https://doi.org/10.5194/acp-13-2452013, 2013.

Caliz, J., Triado-Margarit, X., Camarero, L., and Casamayor, E. O.: A long-term survey unveils strong seasonal patterns in the airborne microbiome coupled to general and regional atmospheric circulations, Proc. Natl. Acad. Sci. USA, 115, 12229-12234, https://doi.org/10.1073/pnas.1812826115, 2018.

Conen, F., Morris, C. E., Leifeld, J., Yakutin, M. V., and Alewell, C.: Biological residues define the ice nucleation properties of soil dust, Atmos. Chem. Phys., 11, 9643-9648, https://doi.org/10.5194/acp-11-9643-2011, 2011.

Creamean, J. M., Suski, K. J., Rosenfeld, D., Cazorla, A., DeMott, P. J., Sullivan, R. C., White, A. B., Ralph, F. M., Minnis, P., Comstock, J. M., Tomlinson, J. M., and Prather, K. A.: Dust and biological aerosols from the Sahara and Asia influence precipitation in the western U.S., Science, 339, 1572-1578, https://doi.org/10.1126/science.1227279, 2013.

Delort, A.-M., Vaïtilingom, M., Amato, P., Sancelme, M., Parazols, M., Mailhot, G., Laj, P., and Deguillaume, L.: A short overview of the microbial population in clouds: potential roles in atmospheric chemistry and nucleation processes, Atmos. Res., 98 249-260, https://doi.org/10.1016/j.atmosres.2010.07.004, 2010.

Després, V. R., Nowoisky, J. F., Klose, M., Conrad, R., Andreae, M. O., and Pöschl, U.: Characterization of primary biogenic aerosol particles in urban, rural, and high-alpine air by DNA sequence and restriction fragment analysis of ribosomal RNA genes, Biogeosciences, 4, 1127-1141, https://doi.org/10.5194/bg-4-11272007, 2007.

Després, V. R., Huffman, J. A., Burrows, S. M., Hoose, C., Safatov, A. S., Buryak, G., Fröhlich-Nowoisky, J., Elbert, W., Andreae, M. O., and Pöschl, U.: Primary biological aerosol particles in the atmosphere: a review, Tellus B, 64, 15598, https://doi.org/10.3402/tellusb.v64i0.15598, 2012.

Fenchel, T. and Finlay, B. J.: The ubiquity of small species: patterns of local and global diversity, BioScience, 54, 777-784, https://doi.org/10.1641/00063568(2004)054[0777:TUOSSP]2.0.CO;2, 2004.

Fröhlich-Nowoisky, J., Ruzene Nespoli, C., Pickersgill, D. A., Galand, P. E., Müller-Germann, I., Nunes, T., Gomes Cardoso, J., Almeida, S. M., Pio, C., Andreae, M. O., Conrad, R., Pöschl, U., and Després, V. R.: Diversity and seasonal dynamics of airborne archaea, Biogeosciences, 11, 6067-6079, https://doi.org/10.5194/bg-11-6067-2014, 2014.

Fröhlich-Nowoisky, J., Kampf, C. J., Weber, B., Huffman, J. A., Pöhlker, C., Andreae, M. O., Lang-Yona, N., Burrows, S. M., Gunthe, S. S., Elbert, W., Su, H., Hoor, P., Thines, E., Hoffmann, T., Després, V. R., and Pöschl, U.: Bioaerosols in the Earth system: climate, health, and ecosystem interactions, Atmos. Res., 182, 346-376, https://doi.org/10.1016/j.atmosres.2016.07.018, 2016.

Griffin, D. W.: Atmospheric movement of microorganisms in clouds of desert dust and implications for human health, Clin. Microbiol. Rev., 20, 459-477, https://doi.org/10.1128/CMR.00039-06, 2007.

Hara, K. and Zhang, D.: Bacterial abundance and viability in long-range transported dust, Atmos. Environ., 47, 20-25, https://doi.org/10.1016/j.atmosenv.2011.11.050, 2012.

Hara, K., Zhang, D., Yamada, M., Matsusaki, H., and Arizono, K.: A detection of airborne particles carrying viable bacteria in an urban atmosphere of Japan, Asian J. Atmos. Environ., 5, 152 156, https://doi.org/10.5572/ajae.2011.5.3.152, 2011.

He, M., Ichinose, T., Yoshida, S., Yamamoto, S., Inoue, K., Takano, H., Yanagisawa, R., Nishikawa, M., Mori, I., Sun, G., and Shibamoto, T.: Asian sand dust enhances murine lung inflamma- 
tion caused by Klebsiella pneumoniae, Toxicol. Appl. Pharmacol., 258, 237-247, https://doi.org/10.1016/j.taap.2011.11.003, 2012.

Hu, W., Murata, K., Fukuyama, S., Kawai, Y., Oka, E., Uematsu, M., and Zhang, D.: Concentration and Viability of Airborne Bacteria Over the Kuroshio Extension Region in the Northwestern Pacific Ocean: Data From Three Cruises, J. Geophys. Res.-Atmos., 122, 12892-12905, https://doi.org/10.1002/2017jd027287, 2017.

Huffman, J. A., Treutlein, B., and Pöschl, U.: Fluorescent biological aerosol particle concentrations and size distributions measured with an Ultraviolet Aerodynamic Particle Sizer (UVAPS) in Central Europe, Atmos. Chem. Phys., 10, 3215-3233, https://doi.org/10.5194/acp-10-3215-2010, 2010

Iwasaka, Y., Shi, G.-Y., Yamada, M., Kobayashi, F., Kakikawa, M., Maki, T., Naganuma, T., Chen, B., Tobo, Y., and Hong, C.: Mixture of Kosa (Asian dust) and bioaerosols detected in the atmosphere over the Kosa particles source regions with balloonborne measurements: possibility of long-range transport, Air Qual. Atmos. Health, 2, 29-38, https://doi.org/10.1007/s11869009-0031-5, 2009.

Joung, Y. S., Ge, Z., and Buie, C. R.: Bioaerosol generation by raindrops on soil, Nat. Commun., 8, 14668, https://doi.org/10.1038/ncomms14668, 2017.

Kasprzyk, I. and Walanus, A.: Gamma, Gaussian and logistic distribution models for airborne pollen grains and fungal spore season dynamics, Aerobiologia (Bologna), 30, 369-383, https://doi.org/10.1007/s10453-014-9332-8, 2014.

Lighthart, B.: The ecology of bacteria in the alfresco atmosphere, FEMS Microbiol. Ecol., 23, 263-274, https://doi.org/10.1111/j.1574-6941.1997.tb00408.x, 1997.

Lighthart, B.: Mini-review of the concentration variations found in the alfresco atmospheric bacterial populations, Aerobiologia, 16, 7-16, https://doi.org/10.1023/A:1007694618888, 2000.

Limpert, E., Burke, J., Galan, C., del Mar Trigo, M., West, J. S., and Stahel, W. A.: Data, not only in aerobiology: how normal is the normal distribution?, Aerobiologia, 24, 121-124, https://doi.org/10.1007/s10453-008-9092-4, 2008.

Maki, T., Susuki, S., Kobayashi, F., Kakikawa, M., Yamada, M., Higashi, T., Chen, B., Shi, G., Hong, C., and Tobo, Y.: Phylogenetic diversity and vertical distribution of a halobacterial community in the atmosphere of an Asian dust (KOSA) source region, Dunhuang City, Air Qual. Atmos. Health, 1, 81-89, https://doi.org/10.1007/s11869-008-0016-9, 2008.

Maki, T., Kakikawa, M., Kobayashi, F., Yamada, M., Matsuki, A., Hasegawa, H., and Iwasaka, Y.: Assessment of composition and origin of airborne bacteria in the free troposphere over Japan, Atmos. Environ., 74, 73-82, https://doi.org/10.1016/j.atmosenv.2013.03.029, 2013.

Matthias-Maser, S. and Jaenicke, R.: The size distribution of primary biological aerosol particles with radii $>0.2 \mu \mathrm{m}$ in an urban/rural influenced region, Atmos. Res., 39, 279-286, https://doi.org/10.1016/0169-8095(95)00017-8, 1995.

Matthias-Maser, S. and Jaenicke, R.: The size distribution of primary biological aerosol particles in the multiphase atmosphere, Aerobiologia, 16, 207-210, https://doi.org/10.1023/A:1007607614544 2000.

Matthias-Maser, S., Brinkmann, J., and Schneider, W.: The size distribution of marine atmospheric aerosol with regard to pri- mary biological aerosol particles over the South Atlantic Ocean, Atmos. Environ., 33, 3569-3575, https://doi.org/10.1016/S13522310(98)00121-6, 1999.

Möhler, O., DeMott, P. J., Vali, G., and Levin, Z.: Microbiology and atmospheric processes: the role of biological particles in cloud physics, Biogeosciences, 4, 1059-1071, https://doi.org/10.5194/bg-4-1059-2007, 2007.

Montero, A., Dueker, M. E., and O’Mullan, G. D.: Culturable bioaerosols along an urban waterfront are primarily associated with coarse particles, PeerJ, 4, e2827, https://doi.org/10.7717/peerj.2827, 2016.

Morris, C. E., Sands, D. C., Bardin, M., Jaenicke, R., Vogel, B., Leyronas, C., Ariya, P. A., and Psenner, R.: Microbiology and atmospheric processes: research challenges concerning the impact of airborne micro-organisms on the atmosphere and climate, Biogeosciences, 8, 17-25, https://doi.org/10.5194/bg-8-17-2011, 2011.

Murata, K. and Zhang, D.: Applicability of LIVE/DEAD BacLight stain with glutaraldehyde fixation for the measurement of bacterial cell concentration and viability in the air, Aerosol Air Qual. Res., 13, 1755-1767, https://doi.org/10.4209/aaqr.2012.10.0293, 2013.

Murata, K. and Zhang, D.: Concentration of bacterial aerosols in response to synoptic weather and land-sea breeze at a seaside site downwind of the Asian continent, J. Geophys. Res.-Atmos., 121, 11636-11647, https://doi.org/10.1002/2016jd025028, 2016.

Polymenakou, P. N., Mandalakis, M., Stephanou, E. G., and Tselepides, A.: Particle size distribution of airborne microorganisms and pathogens during an Intense African dust event in the eastern Mediterranean, Environ. Health Perspect., 116, 292-296, https://doi.org/10.1289/ehp.10684, 2008.

Portillo, M. C., Leff, J. W., Lauber, C. L., and Fierer, N.: Cell size distributions of soil bacterial and archaeal taxa, Appl. Environ. Microbiol., 79, 7610-7617, 2013.

Pöschl, U. and Shiraiwa, M.: Multiphase chemistry at the atmosphere-biosphere interface influencing climate and public health in the anthropocene, Chem. Rev., 115, 4440-4475, https://doi.org/10.1021/cr500487s, 2015.

Pöschl, U., Martin, S. T., Sinha, B., Chen, Q., Gunthe, S. S., Huffman, J. A., Borrmann, S., Farmer, D. K., Garland, R. M., Helas, G., Jimenez, J. L., King, S. M., Manzi, A., Mikhailov, E., Pauliquevis, T., Petters, M. D., Prenni, A. J., Roldin, P., Rose, D., Schneider, J., Su, H., Zorn, S. R., Artaxo, P., and Andreae, M. O.: Rainforest aerosols as biogenic nuclei of clouds and precipitation in the Amazon, Science, 329, 1513-1516, https://doi.org/10.1126/science.1191056, 2010.

Pósfai, M., Li, J., Anderson, J. R., and Buseck, P. R.: Aerosol bacteria over the Southern Ocean during ACE-1, Atmos. Res., 66, 231-240, https://doi.org/10.1016/s0169-8095(03)00039-5, 2003.

Pratt, K. A., DeMott, P. J., French, J. R., Wang, Z., Westphal, D. L., Heymsfield, A. J., Twohy, C. H., Prenni, A. J., and Prather, K. A.: In situ detection of biological particles in cloud ice-crystals, Nat. Geosci., 2, 398-401, https://doi.org/10.1038/ngeo521, 2009.

Prospero, J. M., Blades, E., Mathison, G., and Naidu, R.: Interhemispheric transport of viable fungi and bacteria from Africa to the Caribbean with soil dust, Aerobiologia, 21, 1-19, https://doi.org/10.1007/s10453-004-5872-7, 2005. 
Raisi, L., Aleksandropoulou, V., Lazaridis, M., and Katsivela, E.: Size distribution of viable, cultivable, airborne microbes and their relationship to particulate matter concentrations and meteorological conditions in a Mediterranean site, Aerobiologia, 29, 233-248, https://doi.org/10.1007/s10453-012-9276-9, 2013.

Reinmuth-Selzle, K., Kampf, C. J., Lucas, K., Lang-Yona, N., Frohlich-Nowoisky, J., Shiraiwa, M., Lakey, P. S. J., Lai, S., Liu, F., Kunert, A. T., Ziegler, K., Shen, F., Sgarbanti, R., Weber, B., Bellinghausen, I., Saloga, J., Weller, M. G., Duschl, A., Schuppan, D., and Pöschl, U.: Air Pollution and Climate Change Effects on Allergies in the Anthropocene: Abundance, Interaction, and Modification of Allergens and Adjuvants, Environ. Sci. Technol., 51, 4119-4141, https://doi.org/10.1021/acs.est.6b04908, 2017.

Savage, N. J., Krentz, C. E., Könemann, T., Han, T. T., Mainelis, G., Pöhlker, C., and Huffman, J. A.: Systematic characterization and fluorescence threshold strategies for the wideband integrated bioaerosol sensor (WIBS) using size-resolved biological and interfering particles, Atmos. Meas. Tech., 10, 4279-4302, https://doi.org/10.5194/amt-10-4279-2017, 2017.

Schuerger, A. C., Smith, D. J., Griffin, D. W., Jaffe, D. A., Wawrik, B., Burrows, S. M., Christner, B. C., Gonzalez-Martin, C., Lipp, E. K., Schmale Iii, D. G., and Yu, H.: Science questions and knowledge gaps to study microbial transport and survival in Asian and African dust plumes reaching North America, Aerobiologia, 34, 425-435, https://doi.org/10.1007/s10453-018-95417, 2018.

Shaffer, B. T. and Lighthart, B.: Survey of culturable airborne bacteria at four diverse locations in Oregon: urban, rural, forest, and coastal, Microb. Ecol., 34, 167-177, https://doi.org/10.1007/s002489900046, 1997.

Shi, J., Wang, N., Gao, H., Baker, A. R., Yao, X., and Zhang, D.: Phosphorus solubility in aerosol particles related to particle sources and atmospheric acidification in Asian continental outflow, Atmos. Chem. Phys., 19, 847-860, https://doi.org/10.5194/acp-19-847-2019, 2019.
Tobo, Y., Adachi, K., DeMott, P. J., Hill, T. C. J., Hamilton, D. S., Mahowald, N. M., Nagatsuka, N., Ohata, S., Uetake, J., Kondo, Y., and Koike, M.: Glacially sourced dust as a potentially significant source of ice nucleating particles, Nat. Geosci., 12, 253-258, https://doi.org/10.1038/s41561-019-0314-x, 2019.

Tong, Y. and Lighthart, B.: The annual bacterial particle concentration and size distribution in the ambient atmosphere in a rural area of the Willamette Valley, Oregon, Aerosol Sci. Technol., 32, 393-403, https://doi.org/10.1080/027868200303533, 2000.

Uno, I., Eguchi, K., Yumimoto, K., Takemura, T., Shimizu, A., Uematsu, M., Liu, Z., Wang, Z., Hara, Y., and Sugimoto, N.: Asian dust transported one full circuit around the globe, Nat. Geosci., 2, 557-560, https://doi.org/10.1038/ngeo583, 2009.

Yamaguchi, N., Ichijo, T., Baba, T., and Nasu, M.: Long-range transportation of bacterial cells by Asian dust, Genes and Environment, 36, 145-151, https://doi.org/10.3123/jemsge.2014.015, 2014.

Yue, S., Ren, H., Fan, S., Wei, L., Zhao, J., Bao, M., Hou, S., Zhan, J., Zhao, W., Ren, L., Kang, M., Li, L. Zhang, Y., Sun, Y., Wang, Z., and Fu, P.: High abundance of fluorescent biological aerosol particles in winter in Beijing, China, ACS Earth Space Chem., 1, 493-502, https://doi.org/10.1021/acsearthspacechem.7b00062, 2017.

Zhang, D.: Effect of sea salt on dust settling to the ocean, Tellus B Chem. Phys. Meteorol., 60B, 641-646, https://doi.org/10.1111/j.1600-0889.2008.00358.x, 2008.

Zhang, D., Iwasaka, Y., Shi, G., Zang, J., Matsuki, A., and Trochkine, D.: Mixture state and size of Asian dust particles collected at southwestern Japan in spring 2000, J. Geophys. Res.Atmos., 108, 4760, https://doi.org/10.1029/2003jd003869, 2003.

Zhang, D., Murata, K., Hu, W., Yuan, H., Li, W., Matsusaki, H., and Kakikawa, M.: Concentration and viability of bacterial aerosols associated with weather in Asian continental outflow: current understanding, Aerosol Sci. Eng., 1, 66-77, https://doi.org/10.1007/s41810-017-0008-y, 2017. 